\title{
Innovation and Development trend of Cross-border Electronic Commerce Logistics Model

\author{
Xunyang Feng
}

Jiangxi Vocational Technical College of Industry \& Trade, Jiangxi, Nanchang, 330038

key words Cross-border e-commerce; logistics model; problem; innovation and development

\begin{abstract}
With the economic globalization, the scale of China's foreign trade is becoming larger and larger, followed by the cross-border e-commerce logistics model, but at this stage, because the development time of cross-border e-commerce logistics model in China is still relatively short, and there are not many successful experiences to learn from, so there are still many problems hidden in it. This paper also focuses on the innovation and development trend of cross-border e-commerce logistics model.
\end{abstract}

\section{The Development of Electronic Commerce}

\subsection{Development status of Cross-border Logistics in Electronic Commerce}

The rapid development of our economy in the new era, whether it is a country or a society, has provided very much help in the back of the economic development, and based on this, it has entered the age of e-commerce. The so-called e-commerce era refers to the fact that people have started to accept the electronic commerce in a large scale, and the electronic commerce has played a very important role in the people's life, and there are also more and more people entering the e-commerce market to carry out the related transaction of electronic commerce, Because of the popularity of e-commerce, the development of the logistics industry has also been promoted, and the domestic logistics business has not been able to meet the needs of people, and cross-border logistics It has entered people's field of vision, but there are still many aspects that need to be improved in China's cross-border logistics, so China should also strengthen the promotion of cross-border logistics development.

\subsection{The basic Concepts and characteristics of Cross-border Electronic Commerce}

Cross-border e-commerce relies on e-commerce platform, only on the e-commerce platform can cross-border logistics transactions, but from another point of view, it can also be said that the completion of transactions depends on cross-border logistics, and cross-border e-commerce is an international transaction behavior, which can promote the development of international trade. And from the origin point of view, whether electronic commerce or international trade, as well as cross-border electronic commerce, are the same kind of transaction mode, all in order to conclude the transaction and cross different regions to carry out logistics transportation. Under the trend of economic integration, cross - border e - commerce has attracted more attention. It is also very obvious that it is not limited by space and time, because cross-border e-commerce can cross the country for logistics transportation, so as long as people place orders on e-commerce platform, even foreign products, can also be transported to the domestic through cross-border logistics, while e-commerce users can conduct e-commerce transactions at any time, but because different countries have different tax rates and relevant laws, there is still some problems in cross-border e-commerce mode. 


\section{Problems in Cross-border Electronic Commerce Logistics Model}

\begin{tabular}{|c|c|c|}
\hline \multicolumn{2}{|c|}{ Problems in Cross-border Electronic Commerce Logistics Model } \\
\hline $\begin{array}{c}\text { Collaborative development of } \\
\text { cross-border e-commerce and } \\
\text { cross-border logistics }\end{array}$ & $\begin{array}{c}\text { On the Connection of the } \\
\text { Logistics in the Cross-border } \\
\text { Logistics }\end{array}$ & Cross-border logistics \\
\hline $\begin{array}{c}\text { To strengthen the coordinated } \\
\text { development of cross-border } \\
\text { e-commerce and logistics, and to } \\
\text { achieve the win-win cooperation } \\
\text { of e-commerce and logistics. }\end{array}$ & $\begin{array}{c}\text { Optimize the effective } \\
\text { optimize the information query } \\
\text { function of logistics, and } \\
\text { provide convenient services for } \\
\text { the majority of consumers. }\end{array}$ & $\begin{array}{c}\text { Fully considering the service function } \\
\text { of logistics, strengthening the } \\
\text { communication and communication } \\
\text { among the countries involved, } \\
\text { mastering the taxes and fees of these } \\
\text { countries, trade barriers and other } \\
\text { issues, so as to clear the obstacles for } \\
\text { the development of cross-border } \\
\text { e-commerce in China. }\end{array}$ \\
\hline
\end{tabular}

\subsection{Collaborative development of cross-border e-commerce and cross-border logistics}

Because China's economy is developing very rapidly, the requirements for cross-border e-commerce are becoming higher and higher, and in this case, it is bound to strengthen the coordinated development of cross-border e-commerce, and China must also be able to promote the development of cross-border logistics while conducting e-commerce transactions, because cross-border e-commerce and cross-border logistics complement each other. The development of cross-border e-commerce will lead to the development of cross-border logistics, and the development of cross-border logistics can naturally strengthen the development of cross-border e-commerce. It is self-evident that the development of electronic commerce plays an important role in promoting the economy of our country. The economic market of our country develops in the electronic commerce. With the help of the exhibition, a wide range of broadening has been obtained. But if it takes a long time to carry out cross-border e-commerce, it will not only promote the economy, but also affect the development of the economy. Therefore, we should strengthen the coordinated development of cross-border e-commerce and cross-border logistics.

\subsection{On the Connection of the Logistics in the Cross-border Logistics}

In the transportation process of cross-border logistics, there will be a lot of procedures, the completion of these procedures will take a lot of time, so in order to make cross-border logistics can be transported normally, we must consider the internal logistics convergence of cross-border logistics. Moreover, the coordination of cross-border logistics development in China is obviously very insufficient, resulting in great differences between domestic logistics and cross-border logistics, which will also delay a lot of time, so in order to avoid this problem, we should strengthen the connection of different transport modes. So that the internal transport procedures of cross-border logistics can be effectively reduced, but also the efficiency of cross-border logistics can be improved.

\subsection{Cross-border logistics}

Because the service object of cross-border logistics is not single, in the development of cross-border logistics, the problem of language is also taken into account, only the language problem is solved, and the cross-border logistics can be better developed. However, the cross-border logistics development in our country is not very successful at present because of the obstacles to the development of cross-border logistics. But with the development of economy as the background, the development of logistics will only become more and more rapid, so it also emphasizes that more efforts should be made in our country to clear more obstacles for the development of cross-border e-commerce. 


\section{Innovation and Development trend of Cross-border Electronic Commerce Logistics Model}

\subsection{Strengthen the sharing of logistics mode}

In the development of cross-border e-commerce, it is very important to strengthen the sharing of logistics model, and it is necessary to combine all aspects in order to achieve the agglomeration effect. In the transportation process of cross-border logistics, both commodity inspection and customs situation still exist and have not yet been solved. To some extent, cross-border logistics is more complex and takes longer than domestic logistics process, but cross-border logistics also faces a larger customer base, and in these customer groups, the level of economic development is also different, so it also has a certain impact on logistics. Strengthening logistics model sharing is to eliminate these. Impact。

\subsection{Encourage the development of logistics outsourcing model}

It is not uncommon to establish their own cross-border e-commerce logistics system, but many e-commerce adopt third-party intervention logistics model, and third-party intervention logistics model will affect the distribution process, which will make the distribution process more complex. However, the third party intervention logistics model can transfer the logistics risk to a certain extent, if there are problems in the process of transportation, it is also the responsibility of the third party logistics company. But also because of the popularity of the third party logistics outsourcing model, promote the development of logistics enterprises, so that the logistics chain can be integrated, but also so that the logistics transportation route can be more optimized. At the same time, the logistics outsourcing model is also Can make logistics service more personalized, but also can make the development of logistics model more professional.

\section{Conclusion:}

To sum up, with the background of global economic integration, cross-border e-commerce has become the inevitable trend of the times at this stage. Although the cross-border e-commerce model in China is applied late, but the speed of development is very rapid. Cross-border e-commerce not only facilitates people's daily shopping, but also connects China and the world, so that people can also understand the world more through cross-border e-commerce, which is not restricted by the country. However, it is difficult to fully realize cross-border logistics, which is due to the limitations of network technology and the resource problems between logistics. However, I believe that in the near future, China's cross-border e-commerce model is bound to be available. To universal application.

\section{References:}

[1] Analysis on the Innovation and Development trend of Environmental Electronic Commerce Logistics Model[J]. Biqian. Southern entrepreneurs . 2018(01)

[2] Development direction and innovation path of cross-border e-commerce logistics model. [J]. Jin Rilan . Modern business . 2017(11)

[3] Research on Innovation and Development of Cross-border Electronic Commerce Logistics Model[J]. Zhangbei . Modern Economic Information . 2018(09)

[4] Analysis on Innovation and Development trend of Cross-border Electronic Commerce Logistics Model[J] . Guohe . Management informatization in China . 2019(09)

[5] Research on the Innovation and Development Trend of Cross-border E-commerce Logistics[J]. Fengran. Pay taxes . 2019(07)

[6] Thoughts on the Innovation and Development trend of Cross-border Electronic Commerce Logistics Model[J] . Shijing . National circulation economy . 2019(06)

[7] The innovation and development trend of cross-border e-commerce logistics in China [J] . Liu Xiaoqin . Chinese and foreign entrepreneurs . 2018(12) 